\title{
Journal of Natural Resources and Environmental Management
}

11(4): 662-676. http://dx.doi.org/10.29244/jpsl.11.4.662-676

E-ISSN: 2460-5824

http://journal.ipb.ac.id/index.php/jpsl

\section{The role of stakeholders in conservation governance in the upstream Bedadung Watershed}

Jenitra Milan Petrina ${ }^{a}$, Luh Putu Suciati ${ }^{\mathrm{b}}$, Idah Andriyanic

\footnotetext{
${ }^{a}$ Management of Water Resources Agriculture/Natural Enviroment Study Program, Postgraduate, Jember University, Jember, 68121, Indonesia [+62 85655044868]

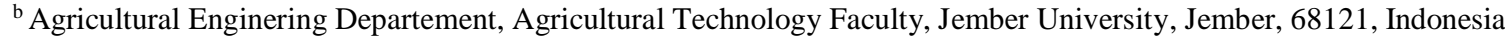

${ }^{\mathrm{c}}$ Agribusiness Department, Agriculture Faculty, Jember University, Jember, 68121, Indonesia
}

\section{Article Info:}

Received: 25 - 07 - 2021

Accepted: 03 - 01 - 2021

\section{Keywords:}

Conservation, governance, stakeholders, upstream, watershed

\section{Corresponding Author:} Idah Andriyani

Agricultural Enginering Department, Agricultural Technology Faculty, Jember University;

Tel.+62-331-323567

Email:

idahandriyani@unej.ac.id

\begin{abstract}
The upstream of the Bedadung Watershed is a catchment area. Now it is not function optimally because of illegal logging and the change in a protected forest to production forest. The purpose of this research was to identify conservation activities in the upstream area using an exploratory, descriptive analysis and to identify the role of stakeholders in the governance of upstream Bedadung Watershed using The Four Rs analysis, while the power and influence of stakeholders use an analysis of stakeholder strengths. The result of the first purpose: (1) coffee plants, teak plants and terraces, cover crops, DAM controller in Jompo Sub-watershed (2) durian terracing, use of organic mulch, sengon plants with elephant grass in Antrokan Sub-watershed (3) planting cover crops, coffee and lamtoro terracing, sengon, coffee and terrace, reforestation with matoah, durian, avocado, petai, and guava in Rempangan Sub-watershed (4) grass strips, cover crops, lamtoro, coffee, and terrace in Rembangan Sub-watershed. The results of the second purpose: in quadrant 1 are LMDH and KTH as Subject have high interest and low influence, quadrant 2 Jember Regional Forestry Service, Public Company Perhutani Forest Management Unit Jember, and BPDASHL Brantas Sampean as Key Player have high interest and influence, quadrant 3 Jember Regency Enviromental Service, Regional Planning and Development Agency Jember, Development of Public Works Highways Jember Regency, and Department of Food Crops Jember Regency as Context Setters have low interest and high influence, and quadrant 4 is Brantas Sampean Watershed Forum as crowd have low interest and influence.
\end{abstract}

How to cite (CSE Style $8^{\text {th }}$ Edition):

Petrina JM, Suciati LP, Andriyani I. 2021. The role of stakeholders in conservation governance in the upstream Bedadung Watershed. JPSL 11(4): 662-676. http://dx.doi.org/10.29244/jpsl.11.4.662-676.

\section{INTRODUCTION}

Pramono (2021) stated that Indonesia has 458 watersheds consisting of 60 watersheds in severely critical condition, 222 watersheds in a moderate critical state, and 176 watersheds with potentially urgent needs. The watershed has a damage that caused by conversion of forest. Forest that usually can be a water catchment area, currently is not functioning optimally (Arsyad and Ernan, 2008). Regulation Number 26/2009 concerning Spatial Planning, explains that the status of vegetated land use is at least $30 \%$ of the 
watershed area. Meanwhile Mawardi (2010) described that total vegetation area in Java is below 20\% of the watershed area. Watersheds that do not function optimally will cause problems, such as increased erosion, landslides, sedimentation, and flooding (Kartika et al., 2016). Santoso et al. (2013) said that Bedadung watershed is one of the largest watersheds in Jember Regency. Then, Wardhono et al. (2010) explain that of upstream Bedadung watershed, illegal logging of protected forests and changes in forest plants around the Argopuro mountains into plantation crops such as coffee, cocoa, and rubber. The impact of reduced forest land cover is erosion, flooding, and landslides (Rosyidie, 2013). Rohman (2018) shows that the erosion value in the upstream Bedadung is 92.57 tons/ha/year. Ministry of Forestry (2013) also explained that the erosion value of 92.57 tons/ha/year is included in the moderate erosion category.

One of the sub-watersheds in upstream of Bedadung, namely the Rembangan sub-watershed, experienced significant land-use changes up to $34.6 \%$, meaning that the area experienced heavy erosion (Andriyani et al., 2020). It is necessary to carry out soil and water conservation activities. Land use that does not pay attention to conservation principles decreases environmental quality (Arsyad, 1989). The upstream Bedadung Watershed is sought as a conservation area because the forest land cover in the upstream Bedadung watershed decreased by $23.6 \mathrm{~km}^{2}$ from 2008 to 2017 (Kartikasari, 2018), so reforestation activities are needed in the upstream area so that downstream communities continue to enjoy water availability from upstream.

The upstream Bedadung Watershed area is composed of various land users, each with different management. Institutional watershed management is very complex, so it cannot be done alone. Involvement of several parties (stakeholders), both from government institutions and community institutions. The research objectives are (1) to identify soil, and water conservation activities carried out in the upstream Bedadung watershed; (2) to identify the roles, relationships, strengths, and influences of stakeholders in conservation management of the upstream Bedadung Watershed. In the first research objective, problem-solving was carried out with exploratory and descriptive analysis. Problem-solving in the second research objective was carried out by analyzing The Four Rs (Four Rs) and analyzing the strength of stakeholders.

\section{METHOD}

\section{Research Location}

This research is located on the upstream Bedadung Watershed, precisely in four sub-watersheds, namely Rempangan, Rembangan, Jompo, and Antrokan sub-watersheds. The research location was chosen intentionally or purposive method. The location determination is due to the potential for landslides and floods due to changes in land use and more diverse stakeholders, from the agricultural, plantation, forestry, and community institutions sectors. The research location is in Figure 1.

\section{Data Collection}

The research method is an analytical and descriptive method. The analytical approach interprets the analysis results related to stakeholders' role, relationship, influence, and power in implementing governance in the upstream Bedadung watershed. The descriptive method was used for conservation activities in upstream areas based on visible facts (Nazir, 1999) The types of research data are primary and secondary data. The primary data collection method of the interview was conducted using a questionnaire, FGD (focus group discussion), and documentation. Secondary data is obtained from various literature and related agencies, such as agriculture commodities, conservation activities, forest and land rehabilitation activities. The method of selecting key informants is purposive sampling, considering key informants or experts from the management. Stakeholders that are managed in upstream Bedadung watershed are described in Table 1. 
Table 1 Expert informant for upstream Bedadung Watershed management

\begin{tabular}{|c|c|c|c|}
\hline No & $\begin{array}{c}\text { Stakeholder } \\
\text { Category }\end{array}$ & Institution & Expert Informant \\
\hline \multirow[t]{14}{*}{1} & \multirow{14}{*}{$\begin{array}{l}\text { Government } \\
\text { Stakeholders }\end{array}$} & \multirow{4}{*}{ a. Management Center for Watersheds } & Head Evaluation Session for \\
\hline & & & Functional Devision of Forest \\
\hline & & & Ecosystem Control \\
\hline & & & \\
\hline & & \multirow{7}{*}{$\begin{array}{l}\text { b. Public Company Perhutani Forest } \\
\text { Management Unit Jember } \\
\text { c. Jember Regional Forestry Service } \\
\text { d. Regional Planning and Development } \\
\text { Agency Jember } \\
\text { e. Department of Public Works Highways } \\
\text { and Water Resources Jember Regency } \\
\text { f. Jember Regency Enviromental Service }\end{array}$} & Head of Business Planning and \\
\hline & & & Development Section \\
\hline & & & Forest and Land Rehabilitation \\
\hline & & & Analyst \\
\hline & & & Head of Infrasructure and Regional \\
\hline & & & Affairs \\
\hline & & & Head of Water Resources \\
\hline & & \multirow{3}{*}{$\begin{array}{l}\text { g. Department of Food Crops, } \\
\text { Horticulture, and Plantation Jember }\end{array}$} & Head Environmental Pollution and \\
\hline & & & Damage Control \\
\hline & & & Head of Infrastructure \\
\hline \multirow[t]{6}{*}{2} & \multirow{6}{*}{$\begin{array}{l}\text { Community } \\
\text { Stakeholders }\end{array}$} & \multirow[t]{2}{*}{ a. Brantas Sampean Watershed Forum } & Head of Brantas Sampean Watershed \\
\hline & & & Forum \\
\hline & & \multirow{4}{*}{$\begin{array}{l}\text { b. Sucopangepok Lestari Forest Village } \\
\text { Community Institution (LMDH } \\
\text { Sucopangepok Lestari) } \\
\text { c. Forest Farmers Group Makin Makmur } \\
\text { (KTH Makin Makmur) }\end{array}$} & Head of LMDH Sucopangepok \\
\hline & & & Lestari \\
\hline & & & \\
\hline & & & Head of KTH Makin Makmur \\
\hline
\end{tabular}

Source: Primary Data, 2021

\section{Analysis Method}

Data analysis method to answer the first solution objective related to identifying conservation activities in the upstream Bedadung watershed was carried out the exploratory, descriptive analysis. The ideal way describes the actual and accurate facts and the nature of the relationship between the phenomena studied. Identify conservation activities by looking at the seven conservation criteria. According to Fandeli (2012), the seven conservation criteria are protection, restoration, utilization, substitution, maximization, recovery, and integration. The conservation activities in the four sub-watersheds are then selected according to the seven criteria. The second research objective is related to the role and relationship of stakeholders in conservation management in the upstream Bedadung watershed, using the analysis of The Four Rs. According to Suporahardjo (2005), The Four Rs is an analytical tool used to clarify or map the roles played by various stakeholders and the character of the relationship between them. The steps in compiling the Four Rs analysis are as follows: (1) Rights, namely to know the authorities of stakeholders; (2) Responsibilities, namely to see the job of stakeholders; (3) Revenues, namely to find out the benefits or gains obtained; (4) Relationships, which is to find out the relationship between the relevant stakeholders.

The goal is to see an interaction, synergy, sustainability, strength of a relationship, and even to determine conflict or the opportunity for conflict to occur relationship. Signs of stakeholder relations are distinguished by red, blue, and green colors. The blue color means that the relationship is good, the red color indicates that there is conflict, while the green color means that it is pretty good. 
Identification of the power and influence of stakeholders in upstream watershed governance is carried out by analyzing stakeholder strengths. According to Suporahardjo (2005), the analysis of stakeholder strength is a tool to help understand people's influence policies or how policies and institutions affect them. Each stakeholder has a different level of interest and influence (Handayani, 2014). The answers from the informants obtained were then transformed into quantitative data. Then it is done by making criteria of interest and standards of stakeholder influence with five-tiered data measurement (Siregar, 2011). The results value of the level of importance and impact are plotted in a matrix of prestige and power with the following four categories:

1. Key Player is the most active stakeholder in conservation management in the upstream Bedadung Watershed because these stakeholders have high interests and influence.

2. Subject has high importance but low influence. This type of stakeholder is supportive but has little certainty to change the situation. These stakeholders may have a much more significant impact if they cooperate with other stakeholders.

3. Context Setter give high impact but have low importance. Stakeholders who play a role in context setters can be a significant risk and need to be monitored and managed carefully.

4. Crowd are stakeholders with low interest and influence and will consider all the activities they do.

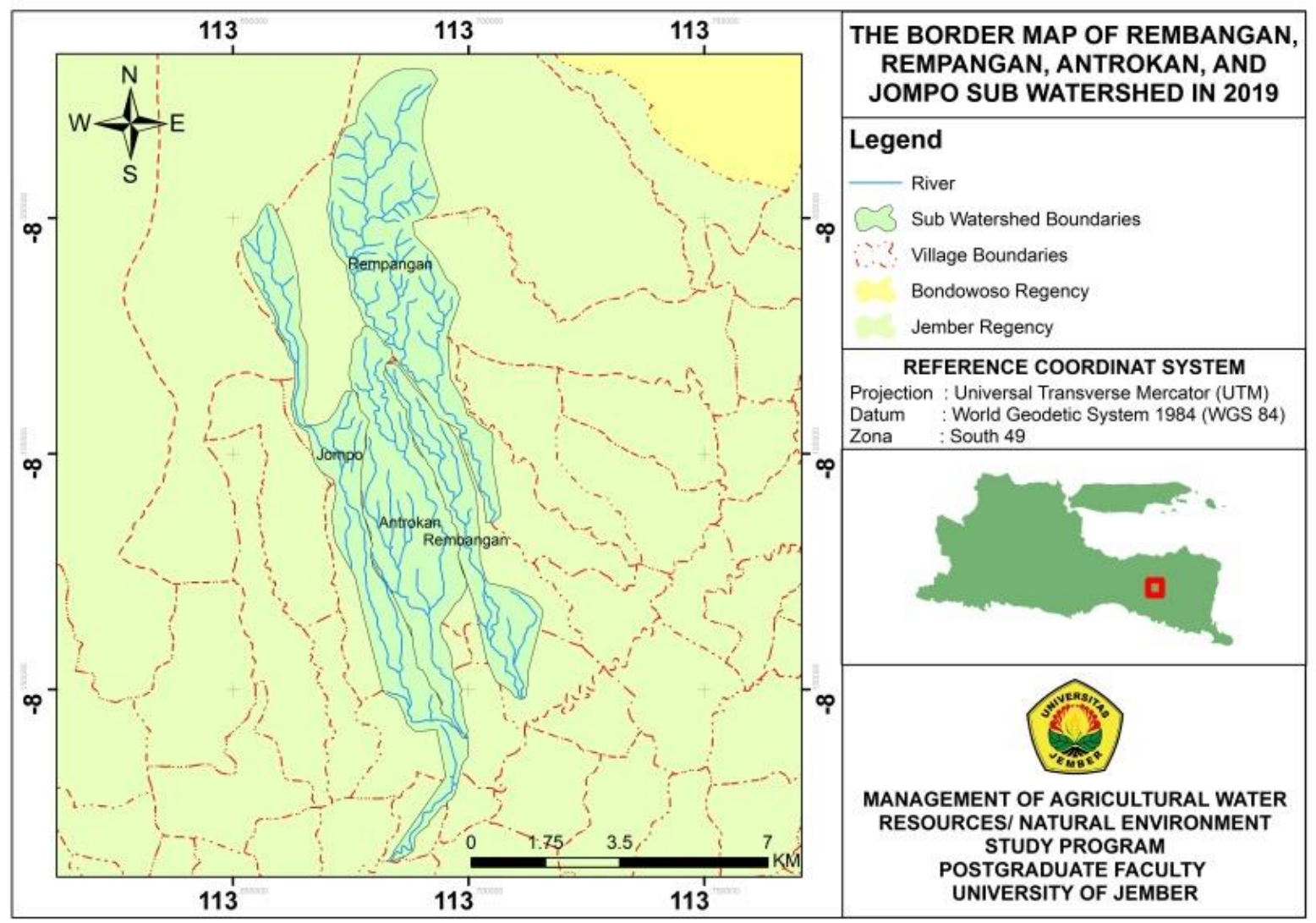

Figure 1 Sub Watershed Antrokan, Jompo, Rembangan, and Rempangan

\section{RESULTS AND DISCUSSION}

\section{Identification of Conservation Activities in the Upstream Bedadung Watershed}

Soil and water conservation activities in each sub-watershed are selected according to the 7 (seven) criteria for conservation activities in using natural resources. Conservation activities in the four subwatersheds obtained from observations are presented in Table 2. 
Table 2 Identification of conservation activities in the Jompo, Antrokan, Rempangan, and Rembangan sub

\begin{tabular}{|c|c|c|c|c|c|c|c|c|c|}
\hline \multirow{3}{*}{ No } & \multicolumn{9}{|c|}{ watersheds } \\
\hline & \multirow{2}{*}{$\begin{array}{c}\text { Sub } \\
\text { Watersehd }\end{array}$} & \multirow{2}{*}{$\begin{array}{c}\text { Conservation } \\
\text { Activities }\end{array}$} & \multicolumn{7}{|c|}{ Conservation Criteria } \\
\hline & & & Protection & Restoration & Utilization & Substitution & Maximization & Recovery & Integration \\
\hline \multirow[t]{3}{*}{1.} & Jompo & $\begin{array}{l}\text { Coffe, teak, } \\
\text { and terrace }\end{array}$ & $\checkmark$ & $\checkmark$ & $\checkmark$ & & $\checkmark$ & & $\checkmark$ \\
\hline & & Cover crop & $\checkmark$ & $\checkmark$ & & & & & \\
\hline & & $\begin{array}{l}\text { DAM } \\
\text { controller }\end{array}$ & $\checkmark$ & $\checkmark$ & $\checkmark$ & & $\checkmark$ & & $\checkmark$ \\
\hline \multirow[t]{3}{*}{2.} & Antrokan & $\begin{array}{l}\text { Durian plant } \\
\text { terrace }\end{array}$ & $\checkmark$ & $\checkmark$ & $\checkmark$ & & $\checkmark$ & & $\checkmark$ \\
\hline & & $\begin{array}{l}\text { Use of } \\
\text { organic } \\
\text { mulch }\end{array}$ & $\checkmark$ & $\checkmark$ & $\checkmark$ & $\checkmark$ & $\checkmark$ & $\checkmark$ & \\
\hline & & $\begin{array}{l}\text { Sengon plant } \\
\text { with elephant } \\
\text { grass, and } \\
\text { terraces }\end{array}$ & $\checkmark$ & $\checkmark$ & $\checkmark$ & & $\checkmark$ & & $\checkmark$ \\
\hline \multirow[t]{5}{*}{3.} & Rempangan & Cover crop & $\checkmark$ & $\checkmark$ & & & & & \\
\hline & & $\begin{array}{l}\text { Terrace with } \\
\text { coffee plants } \\
\text { and lamtoro }\end{array}$ & $\checkmark$ & $\checkmark$ & $\checkmark$ & & $\checkmark$ & & $\checkmark$ \\
\hline & & $\begin{array}{l}\text { Sengon, } \\
\text { coffee, and } \\
\text { terraces }\end{array}$ & $\checkmark$ & $\checkmark$ & $\checkmark$ & & $\checkmark$ & & $\checkmark$ \\
\hline & & $\begin{array}{l}\text { Reforestation } \\
\text { with matoah, }\end{array}$ & & & & & & & \\
\hline & & $\begin{array}{l}\text { sengon, } \\
\text { durian, } \\
\text { avocado, } \\
\text { petai and } \\
\text { guava plants }\end{array}$ & $\checkmark$ & $\checkmark$ & $\checkmark$ & $\checkmark$ & $\checkmark$ & & $\checkmark$ \\
\hline \multirow[t]{3}{*}{4.} & Rembangan & Grass Strip & $\checkmark$ & $\checkmark$ & & & & & \\
\hline & & Cover crop, & $\checkmark$ & $\checkmark$ & & & & & \\
\hline & & $\begin{array}{l}\text { Coffee } \\
\text { plants, } \\
\text { lamtoro, and } \\
\text { Terrace }\end{array}$ & $\checkmark$ & $\checkmark$ & $\checkmark$ & & $\checkmark$ & & $\checkmark$ \\
\hline
\end{tabular}

Source: Primary data, 2021

Suryaningtias (2019) explained that Jompo sub-watershed has a flat slope $0-1 \%$ with 760.6 ha area or $64.50 \%$ of the total area of the Jompo's sub-watershed area. The classification of steep slope is 7.1-12\% with 21.89 ha or $1.89 \%$, while the very steep slope is $12.1-25 \%$ with 8.37 ha or $0.71 \%$ of the total area of the Jompo's sub-watershed area. These conditions illustrate that the conditions slope of Jompo subwatershed is steep and very steep. This steep slope will affect the velocity of the surface runoff against the droplets of water splash to the greater water carrying capacity. This condition cause coffee and teak plant to be cultivated in this area with terraced land to reduce erosion. Coffee plants in Jompo sub-watershed use a simple agroforestry system. Simple agroforestry is an agricultural system in which trees are intercropped with other crops, such as teak and mahogany.

Conservation activities in Antrokan sub-watershed that have been carried out are making durian terraces, using organic mulch and sengon plants, elephant grass, and terracing. Fadila (2019) said that a terrace is a mechanical soil and water conservation building that is made to shorten the length of the slope and or reduce the slope by digging and filling the soil across the slope (Sukartaatmadja, 2004). The function of the terrace is to reduce the length of the slope and retain water, thereby reducing the speed and amount of runoff, and allowing the absorption of water by the soil, thereby reducing erosion (Arsyad, 1989). The use of mulch with straw waste in Slawu Village includes conservation criteria, namely 
reducing, reusing, recycling, and restoring the condition of land that has been used for farming. The mulch used is the rest of the rice plant after harvest, which has been cut into pieces and then spread evenly over the soil surface.

The condition of the land in the Rempangan sub-watershed, espesially in Sucopangepok Village, Jelbuk District, with an altitude of $487 \mathrm{mdpl}$ and has the widest area in Jelbuk District. The conservation activities carried out are cover crops, terracing coffee plants with lamtoro, coffee plants, sengon, and terracing, and reforestation. Tree planting or reforestation is included in all conservation criteria, especially as restoration and replacement materials. Reforestation activities in Sucopangepok Village have been carried out by students of the Postgraduate Program at the University of Jember. The activity was carried out in the context of World Tree Planting Day 2019. The activity was carried out on December 23rd, 2019. There were 10 kinds of seeds given out, namely durian, petai, sengon, klengkeng, jackfruit, matoa, breadfruit, avocado, tail, and guava. The total number of seeds that donated is 3000 seeds.

The Rembangan sub-watershed, especially in Kemuning Lor Village, Arjasa District, has an area of $10.89 \mathrm{~km}^{2}$ and is located at an altitude of $175.45 \mathrm{mdpl}$. Conservation activities in the Rembangan subwatershed area are grass strips, ground cover plants, and lamtoro, coffee, and terracing plants. Planting in strips is a way of farming with several types of plants, planted alternately in strips of a plot of land and arranged to cut slopes or contour lines. Usually, food crops or annuals are interspersed with strips of fastgrowing, dense cover crops for green manure. Kartasapoetra (2010) said that planting annuals plants then interspersed with fast-growing, dense strips of ground cover for green manure. In addition, lamtoro, coffee, and terracing plants were found in one area with an agroforestry system.

\section{The Role of Stakeholders in the Governance of Upstream Bedadung Watershed in terms of Rights,}

\section{Responsibilities, and Revenues}

\section{The Role of BPDASHL Brantas Sampean in Governance in Upstream Bedadung Watershed}

Based on Regulation of the Minister of Environment and Forestry Numb: P.10/MENLHK/SETJEN/O TL.0/1/2016, the role of BPDASHL Brantas Sampean is obtained to carry out the preparation of plans, implementation rehabilitation of forest such as soil and water conservation, institutional development, control of damage to inland waters, and evaluation of the management of watersheds and protected forests based on the provisions of laws and regulations. The rights that obtained by BPDASHL are, the first is guidance in terms of land and rehabilitation, as well as soil and water conservation. The second is BPDASHL's financial support obtained from the central government, namely the Ministry of Environment and Forestry. Aspects of BPDASHL responsibilities, first, namely developing institutions and providing plant seeds for the community. The third is to develop a watershed and protected forest management plan, as well as to develop techniques for forest, land, and water rehabilitation. In terms of revenues, it is the realization of work programs. In 2019, BPDASHL has a work program for the rehabilitation of protected forests, especially around the Bedadung Watershed. Rehabilitation activities were carried out together with Public Company Perhutani Forest Management Unit Jember and Public Company Perhutani Forest Management Unit Jember. The output is data on the location of the protected forest, the area, and the condition of the protected forest.

\section{The Role of Public Company Perhutani Forest Management Unit Jember}

Public Company Perhutani Forest Management Unit Jember is the implementing elements of the government, which has the duty and authority to carry out the planning, management, exploitation, and protection of forests in its working area. The rights to manage forests and fauna and the right to cooperate with communities around the forest. Public Company Perhutani Forest Management Unit Jember cuts trees by taking into account all aspects, such as the age of trees and rehabilitating forests that have been cut 
down. Futhermore, opens space for the community in social and economic aspects. A social aspect is a form of cooperation with the community, while in the economic aspect, the share from the payment of taxes on forests and plants grown under stands is $30 \%$ per harvest season. The responsibilities are maintaining and increasing the carrying capacity and quality of the environment. The revenue aspect obtained is obtaining forest products, agriculture, flora, and fauna. Second, obtain environmental services in the form of tourism potential and natural education, such as Tancak Waterfall in Suci Village, Panti District, SJ88 Tourism in Sucopangepok Village which offers views from the top of the hill.

\section{The Role of Jember Regional Forestry Service}

Jember Regional Forestry Service is the implementing element under the government of East Java Province. The right of Jember Regional Forestry Service, first, rehabilitation outside forest areas, and the right to foster the use and management of forest products with Forest Farmers Groups or KTH. Second, obtaining rehabilitation rights outside the forest area. The application of soil conservation is referred to the Regulation of the Minister of Environment and Forestry Numb: P.105/MENLHK/SETJEN/KUM.1/12/201 8, concerning Procedures for Implementation of Supporting Activities, Giving, Incentives, and Guiding and Controlling Forest and Land Rehabilitation Activities. The responsibility aspect is carrying out rehabilitation and conservation outside the state forest area in its working area. Rehabilitation is carried out using vegetative methods, such as making community forests, establishing agroforestry, establishing village nurseries and providing productive plant seeds. Civil-technical methods, such as Construction of controlling DAM, Retaining DAMs, Infiltration Wells, Embungs and Roraks. The revenue aspect is obtaining forest products in the working area. The second is helping the community to participate in forest conservation. Community participation in forest and watershed conservation is still lacking, because people tend to plant seasonal crops.

\section{The Role of Regional Planning and Development Agency Jember}

Regional Planning and Development Agency Jember is the implementing elements of the government, which has the task of planning, implementing, and coordinating development planning activities. The right is to manage data on the results of activities and analyze technical planning as well as reprimand the technical service if it is not in accordance with the agreement plan. Regional Planning and Development Agency Jember will usually conduct observations and collect data related to the technical implementation of watershed management programs in the Jember Regency area together with the related. Aspects of responsibilities by coordinating the preparation of strategic plans and work plans for environmental affairs and irrigation affairs. The function coordinator in carrying out its duties and responsibilities and is not technically involved in the field. Beside that, also has a role to do monitoring and evaluations of regional develompment. The aspects of revenues are implementing sustainable development and implementing government programs for the long and short term.

\section{The Role of Department of Food Crops, Horticulture, and Plantation Jember Regency}

Department of food crops, horticulture, and plantation Jember Regency is the implementing element of the government which has the task of carrying out the authority of the Jember Regency Regional Government in the field of agriculture and plantation. In terms of right to manage assets task execution unit of agriculture, with sufficient value, because not all agricultural assets task execution unit look active. Aspects of the are coordinating the implementation of programs, technical activities and agricultural extension in its working area, identifying the production needs of food crops, horticulture and plantations, because every year through a survey of the potential of the area and the production needs of food crops. 
Aspects of revenues, namely institutional strengthening has an impact on increasing farmers' resources in terms of planning to post-harvest.

\section{The Role of Department of Public Works Highways and Water Resources Jember Regency}

Department of Public Works Highways and Water Resources Jember Regency in the management of water resources guided by four legal bases, namely: (1) The Law Regulation of Republic Indonesia Number 17 of 2019, concerning Water Resources; (2) Regulation of the Minister of PUPR No. 4 of 2015, concerning Criteria and Determination of Rivers; (3) Regulation of the Minister of PUPR No. 14 of 2015, concerning Criteria and Determination of the Status of Irrigation Areas; (4) East Java Governor Decree No. 188/558/KPTS/013/2019, regarding the Water Resources Management Coordination Team for the Bondoyudo Bedadung River Area. The right of Department of Public Works Highways and Water Resources Jember Regency in the management in upstream Bedadung Watershed has to cooperate with other parties to implement the work program. The responsibilities are preparing a program of activities and estimating the cost of implementing the construction and rehabilitation of irrigation, drainage, and complementary buildings. The revenue aspect is the maintenance of irrigation assets and increasing water availability for farmers.

\section{The Role of Jember Regency Enviromental Service}

The right of Jember Regency Enviromental Service to serve public complaints related to the environment. Often Jember Regency Enviromental Service receives complaints regarding garbage and waste flowing along the riverbanks. The aspect of responsibilities is implementing policies related to environmental maintenance that are in the Regional Medium Term Development Plan 2016-2021. The revenue aspect is the realization of work programs and the development of economic potential through community empowerment.

\section{The Role of Brantas Sampean Watershed Forum}

Brantas Sampean Watershed Forum was formed with the East Java Governor's Decree Number: 188/247/KPTS/013/2018, concerning the Brantas Sampean Watershed Management Coordination Forum for the 2018-2023. The rights is conveying considerations and suggestions in watershed management. According to the Head of Brantas Sampean Watershed Forum, watershed management needs to pay attention to the physical aspects, and mapping the potentials in each watershed, through collaboration with stakeholders including the community around the watershed. Aspects of the responsibilities is to conduct studies on policies, plans, implementation of activities and the impact of watershed management activities as input to decision makers. The revenue is improving the quality and quantity of forest and land rehabilitation. If the policies and main tasks are carried out in accordance with the responsibilities of each stakeholder, the damage to forests and land in the upstream watershed area will be reduced. Environmental damage due to population increase can be minimized with the awareness of all parties.

\section{The Role of LMDH "Sucopangepok Lestari"}

LMDH is a social community institution that supports the achievement of independence through cooperation in the management of forest resources with Public Company Perhutani Forest Management Unit Jember (Noviati, 2014). LMDH's right to receive seed assistance, such as avocado and durian under the auspices of Perhutani's mahony tree. Aspects of responsibilities, the first is taking care of forest plants and intercrops. Second, is to comply with and comply with technical and implementation instructions, and from other stakeholders in partnership with LMDH. The advantage of LMDH is to gain added value from the intercropping crops. 


\section{The Role of KTH "Makin Makmur"}

The rights aspect is getting guidance from forest extension workers. Regulation of the Minister of Forestry of the Republic of Indonesia Number: P.57/Menhut-II/2014, concerning the Guidance of Forest Farmer Groups. Responsibilities are to carry out rehabilitation on critical/empty/unproductive land, go along the road, or on either side of the river. The revenue aspect is obtaining non-timber forest products.

\section{The Role Stakeholders in Upstream Management of the Badadung Watershed in terms of \\ Relationship}

The role of stakeholders in terms of relationship is the communication and cooperation between stakeholders in management of upstream Bedadung watershed. The relationship between stakeholders in the management of upstream Bedadung Watershed is described in Table 3.

Table 3 Stakeholder relationships in the upstream governance of upstream Bedadung Watershed

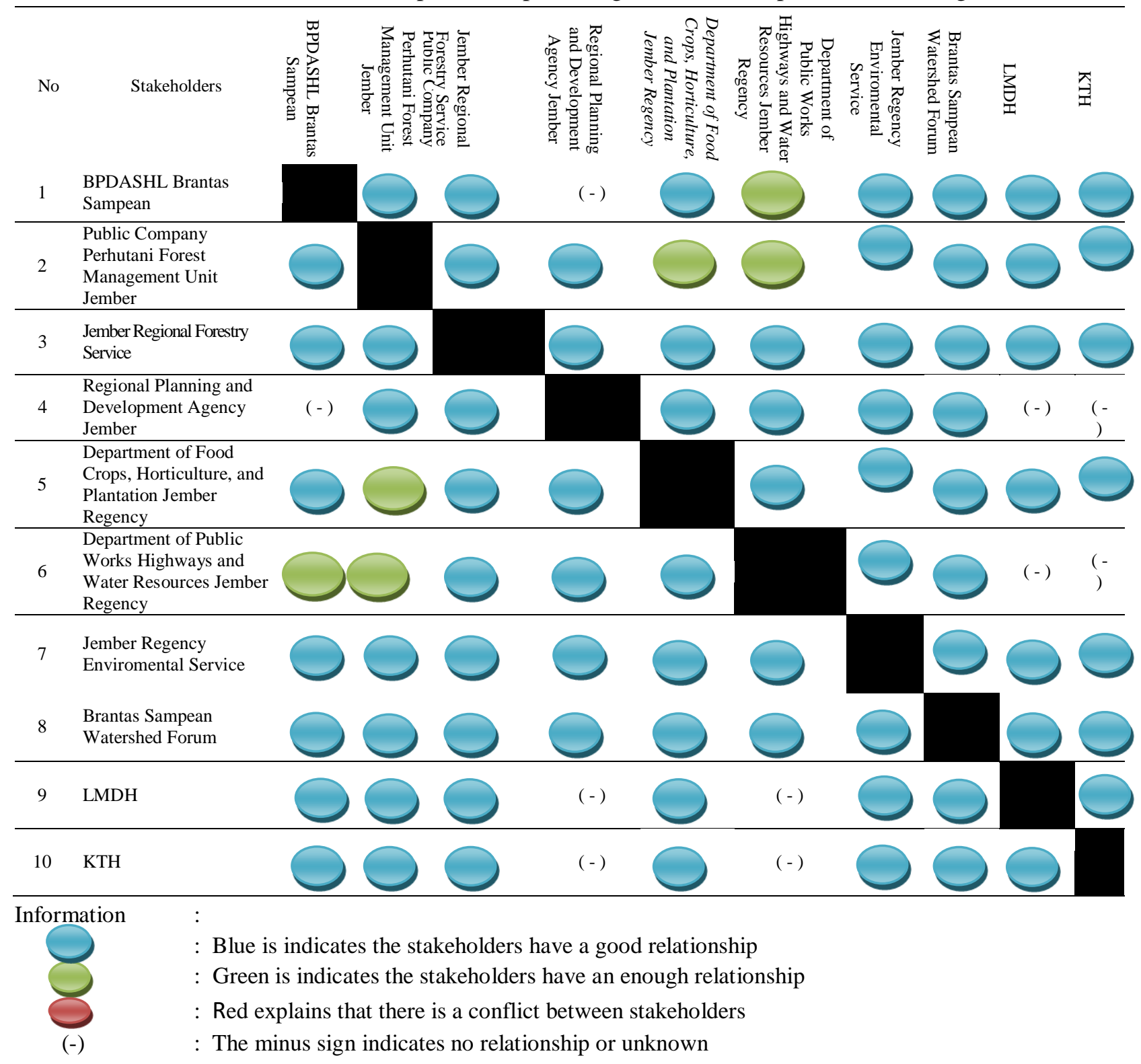


Based on Table 3, most stakeholders relations are marked in blue, meaning that the relationship is good and no conflict. The activity of BPDASHL Brantas Sampean with Public Company Perhutani Forest Management Unit Jember is rehabilitation of protectedforests. BPDASHL Brantas Sampean and Regional Planning and Development Agency Jember have green markings, meaning that the relationship is sufficient because they are directly coordinating with the relevant agencies. There is no red color, it means there is no conflict between stakeholders.

\section{Classification of Stakeholders in the Upstream Bedadung Watershed Governance}

The level stakeholder importance into one of the power factor in upstream Bedadung Watershed governance. The number of stakeholders assessed is ten according to the stakeholders analyzed using The Four Rs analysis (Right, Responsibilities, Revenues, and Relationships). The composition of the influence and importance matrix is carried out on the basis of the description of the informant's questions expressed in quantitative measures or scores (Widodo et al., 2018). The assessment results of the stakeholder importance level are adjusted to the factors that influence the conservation governance in upstream Bedadung Watershed. The level of stakeholder interest is presented in Table 4.

Table 4 Level of stakeholder interest in the governance of upstream Bedadung Watershed

\begin{tabular}{|c|c|c|c|c|c|c|c|}
\hline \multirow{2}{*}{ No } & \multirow{2}{*}{ Stakeholders } & \multicolumn{5}{|c|}{ Importance } & \multirow{2}{*}{ Score } \\
\hline & & I1 & $\mathrm{I} 2$ & I3 & I4 & I5 & \\
\hline 1 & BPDASHL Brantas Sampean & 4 & 4 & 4 & 4 & 4 & 20 \\
\hline 2 & $\begin{array}{l}\text { Public Company Perhutani Forest } \\
\text { Management Unit Jember }\end{array}$ & 5 & 5 & 5 & 5 & 5 & 24 \\
\hline 3 & Jember Regional Forestry Service & 5 & 5 & 5 & 5 & 5 & 23 \\
\hline 4 & $\begin{array}{l}\text { Regional Planning and Development } \\
\text { Agency Jember }\end{array}$ & 2 & 2 & 2 & 2 & 2 & 12 \\
\hline 5 & $\begin{array}{l}\text { Department of Food Crops, } \\
\text { Horticulture, and Plantation Jember } \\
\text { Regency }\end{array}$ & 3 & 3 & 3 & 3 & 3 & 14 \\
\hline 6 & $\begin{array}{l}\text { Department of Public Works } \\
\text { Highways and Water Resources } \\
\text { Jember Regency }\end{array}$ & 4 & 4 & 4 & 4 & 4 & 16 \\
\hline 7 & Jember Regency Enviromental Service & 4 & 4 & 4 & 4 & 4 & 17 \\
\hline 8 & Brantas Sampean Watershed Forum & 3 & 3 & 3 & 3 & 3 & 16 \\
\hline 9 & LMDH & 4 & 4 & 4 & 4 & 4 & 21 \\
\hline 10 & KTH & 4 & 4 & 4 & 4 & 4 & 20 \\
\hline
\end{tabular}

Information: 5: Very high; 4: High; 3: Enough; 2: Less hight; 1: Low

I1 : Expectations of watershed governance program Bedadung

I2: Involvement in the program

I3 : Work program realization

I4 : Profits or benefits obtained

I5 : Resources that can or want to be mobilized

The level of stakeholder interest is influenced by five factors, namely expectations of program governance, involvement in the program, realization of work programs, benefits that obtained, resources that can be mobilized. Expectations for the conservation management program in upstream Bedadung Watershed, such as various forest plant commodities, not only monocultures, but also intercropping with other plants, so that there are additional benefits for the community and institutions. Advantages in the 
environmental aspect are preventing flooding during the rainy season, and reducing the rate of erosion on sloping land.

Involvement in the program means that there are stakeholders who are directly or indirectly involved management process in upstream Bedadung Watershed. Viewed from the identification results, the stakeholders who have a direct interest are BPDASHL Brantas Sampean, Public Company Perhutani Forest Management Unit Jember, and Jember Regional Forestry Service. This is because the stakeholders have a direct role in the process from the beginning of planning, implementing program activities, participating in monitoring and evaluation, making reports, and coaching or learning about their fostered organizations. The realization of the work program is going according to plan, such as the work program of BPDASHL Brantas Sampean, one of its work programs is to rehabilitate land in upstream areas with the community. Stakeholders have often done this by cooperating with universities to help campaign for the community about the importance of protecting the environment by planting trees.

The benefits obtained in the ecological aspect are that people become more concerned with nature and the environment. The economic aspect can increase people's income, hoping that they will be more prosperous. The social aspect of the community is more aware of the importance of maintaining upstream and has knowledge of conservation activities. Stakeholders can mobilize resources of human, for example forest plant products for timber production can only be mobilized by Public Company Perhutani Forest Management Unit Jember, but for intermediary plants mobilized by the community who are members of LMDH, because apart from staple crops, they have become the property of LMDH, according to the division of territory approved by the Notary.

Based on Table 4 can be seen that Public Company Perhutani Forest Management Unit Jember, Jember Regional Forestry Service, and LMDH are included in the high criteria. Public Company Perhutani Forest Management Unit Jember has the highest score, because that has the duties and authority to carry out planning, implementation, exploitation, and forest protection in its working area. The strategic role is to support environmental sustainability systems, socio-cultural systems, and forestry community economic systems, using sustainable forest management principles and the principles of good corporate governance.

Table 5 Level of stakeholders influence in governance of upstream Bedadung Watershed

\begin{tabular}{|c|c|c|c|c|c|c|c|}
\hline \multirow{2}{*}{ No } & \multirow{2}{*}{ Stakeholders } & \multicolumn{5}{|c|}{ Influence } & \multirow{2}{*}{ Score } \\
\hline & & P1 & $\mathrm{P} 2$ & $\mathrm{P} 3$ & $\mathrm{P} 4$ & P5 & \\
\hline 1 & BPDASHL Brantas Sampean & 4 & 4 & 5 & 4 & 5 & 22 \\
\hline 2 & $\begin{array}{l}\text { Public Company Perhutani Forest } \\
\text { Management Unit Jember }\end{array}$ & 5 & 4 & 4 & 5 & 5 & 23 \\
\hline 3 & Jember Regional Forestry Service & 5 & 5 & 5 & 5 & 4 & 24 \\
\hline 4 & $\begin{array}{l}\text { Regional Planning and Development } \\
\text { Agency Jember }\end{array}$ & 4 & 4 & 5 & 5 & 5 & 23 \\
\hline 5 & $\begin{array}{l}\text { Department of Food Crops, } \\
\text { Horticulture, and Plantation Jember } \\
\text { Regency }\end{array}$ & 5 & 4 & 3 & 4 & 3 & 19 \\
\hline 6 & $\begin{array}{l}\text { Department of Public Works } \\
\text { Highways and Water Resources } \\
\text { Jember Regency }\end{array}$ & 3 & 3 & 4 & 4 & 4 & 19 \\
\hline 7 & $\begin{array}{l}\text { Jember Regency Enviromental } \\
\text { Service }\end{array}$ & 4 & 4 & 5 & 4 & 4 & 21 \\
\hline 8 & Brantas Sampean Watershed Forum & 3 & 3 & 3 & 3 & 4 & 16 \\
\hline 9 & LMDH & 4 & 2 & 2 & 3 & 3 & 14 \\
\hline 10 & KTH & 3 & 2 & 2 & 3 & 3 & 13 \\
\hline
\end{tabular}


Information:

5: Very high; 4: High; 3: Enough; 2: Less hight; 1: Low

P1: Power and status (political, social, and economic)

P2: Personal relationship with other stakeholders

P3: Power relations with other stakeholders

P4: Mastery of strategic resources

P5: Decision making in program policy

The level of stakeholder influence is also a determining factor in the strength of stakeholders in the upstream governance of the Bedadung. The results of the assessment of the level of influence of stakeholders in the management of upstream Bedadung Watershed are presented in Table 5.

Based on Table 5, the level of influence that has a very high value in the conservation management of upstream Bedadung Watershed are Jember Regional Forestry Service, Public Company Perhutani Forest Management Unit Jember, BPDASHL Brantas Sampean, Regional Planning and Development Agency Jember, and Jember Regency Enviromental Service. Jember Regional Forestry Service is very influential because its goal is for the welfare of the community. There is no profit, they are just sharing their harvest, directs, and facilitates business institutions. BPDASHL also has a very high influence, because it has a work program that is planning, implementing, monitoring, and evaluating the management of watersheds and protected forests in its working area. In addition, it also carries out forest and land rehabilitation activities, as well as soil and water conservation, develops institutions, and presents information related to the management of watersheds and protected forests in synergy with stakeholders. Siregar (2011) said that the influence of stakeholders is related to power over activities, including monitoring the decisions that have been made, and facilitating the implementation of activities, as well as responding to negative impacts. Sources of influence in the form of regulations or policies, financial support, opinions or opinions, information, and leadership. The influence of stakeholders can be assessed by measuring the size of the ability of these stakeholders to influence or force other stakeholders to follow their decisions.

The value of stakeholder interest and influence in the management of upstream Bedadung watershed is then plotted in a matrix using a stakeholder grid with Microsoft Ecxel. According to Siregar (2011), the matrix of stakeholder interests and influence can change at any time, but needs to be considered. Classification of stakeholder influence and interest levels explained in Figure 2.

Quadrant I (Subject) is occupied by LMDH and KTH, which have a very high interest in the management of upstream Bedadung watershed, but their influence is low. LMDH and KTH have an interest in obtaining added value from the use of intercropping, but because their influence is low. LMDH of Sucopangepok Lestari and KTH have an interest in obtaining added value from the use of intercropping plants on forest land belonging to Public Company Perhutani Forest Management Unit Jember. LMDH and KTH are important stakeholders, but because their influence is low, LMDH and KTH require empowerment in the conservation management of upstream Bedadung watershed.

Quadrant II (Key Player) is occupied by Jember Regional Forestry Service, Public Company Perhutani Forest Management Unit Jember, dan BPDASHL Brantas Sampean. Public Company Perhutani Forest Management Unit Jember has the highest importance value, because forests play a role in maintaining the balance of the environment, forest resources and sources of state income. This stakeholders have the same high interest and influence. Public Company Perhutani Forest Management Unit Jember has the main task of maintaining the sustainability of the state forest located at the foot of Mount Argopuro. Forests have a role in maintaining the balance of the environment and forest resources. In addition, the forest belonging to Public Company Perhutani Forest Management Unit Jember is a source of state income, both timber and non-timber forest products. 


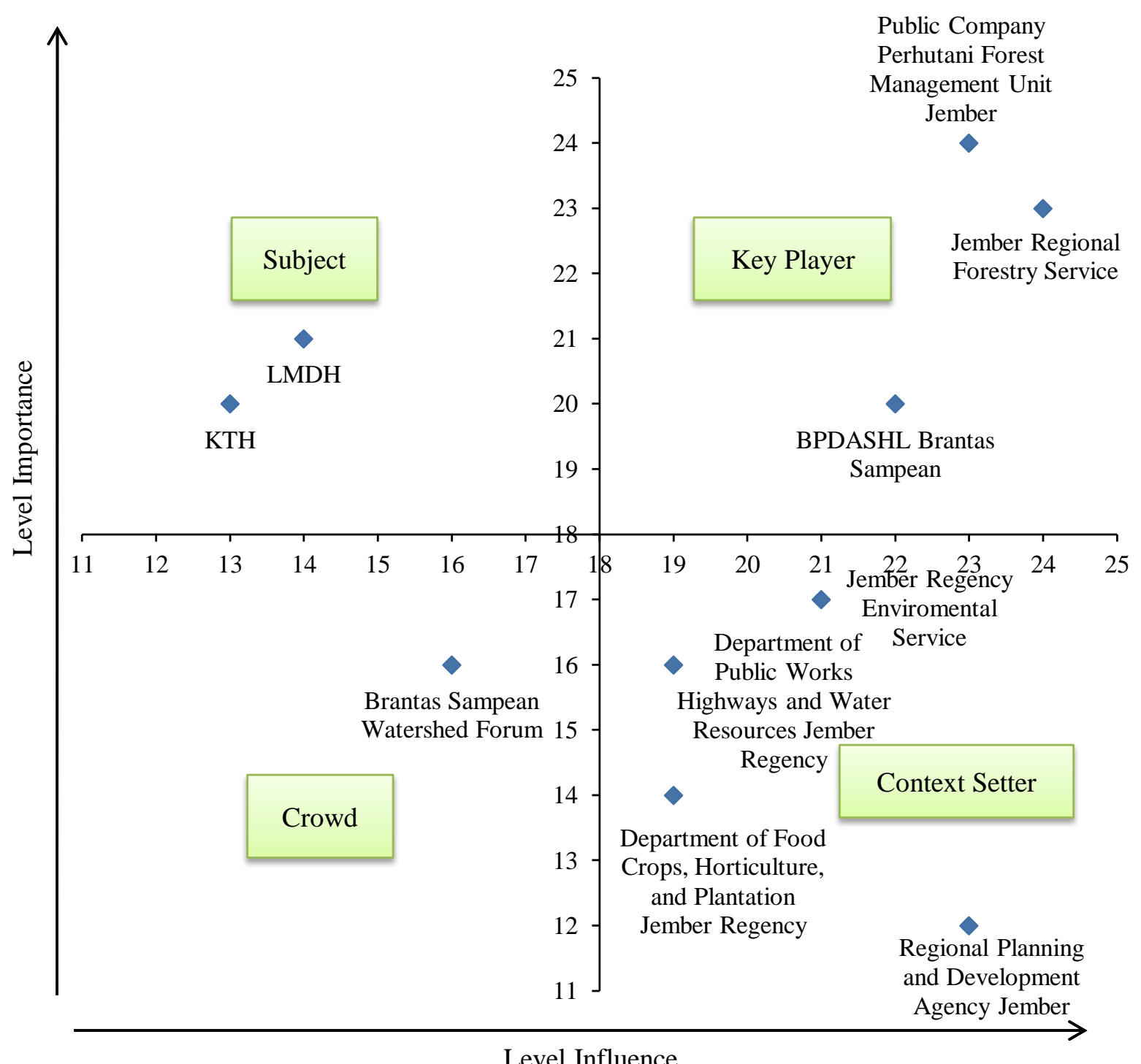

Figure 2 Classification of stakeholder influence and interest levels

Quadrant III (Context Setter) is occupied by Jember regency Enviromental Service, Department of Public Works Highways and Water Resources Jember Regency, Department of Food Crops, Horticulture, and Plantation Jember Regency, and Regional Planning and Development Agency Jember. This stakeholders have low importance, but their positions provide high influence. Siregar (2011) stated that stakeholders in Context Setters can be a significant risk and need to be monitored, and managed carefully. Department of Food Crops, Horticulture, and Plantation Jember Regency can influence management of upstream Bedadung Watershed, because it has strong institutions, namely the association of water user farmers or HIPPA and farmer groups who depend on the availability of water during the dry season. Regional Planning and Development Agency Jember is also has a influence in the management of upstream Bedadung Watershed, because as the coordinator of Department Jember Regency, who participates in planning activities and monitoring evaluations, but does not participate in the implementation of activities, just refers to the main tasks and functions of the Jember Regency's Regional Spatial Plan. 
Quadrant IV (Crowd), is the Brantas Sampean Watershed Forum. It means that Brantas Sampean Watershed Forum in the crowd position. It has low interest and low influence on the conservation management of upstream Bedadung Watershed. Brantas Sampean Watershed Forum in its implementation, looks has very little role and involvement in activities and provides input on policies related to watershed planning to relevant stakeholders or often as a technical department consultant related to watershed management. According to Widiyanti (2016), the crowd is a stakeholder who has the position of an observer, so when they lose Brantas Sampean Watershed Forum, it will not have much influence on the governance of upstream Bedadung Watershed.

\section{CONCLUSION}

Conservation activities in the upstream Bedadung Watershed are (1) coffee plants, teak plants and terraces, cover crops, DAM controller in Jompo Sub-watershed (2) durian terracing, use of organic mulch, sengon plants with elephant grass in Antrokan Sub-watershed (3) planting cover crops, coffee and lamtoro terracing, sengon, coffee and terrace, reforestation with matoah, durian, avocado, petai, and guava in Rempangan Sub-watershed (4) grass strips, cover crops, lamtoro, coffee, and terrace in Rembangan Subwatershed. The results of the second purpose about position and role of each stakeholder managing the upstream Bedadung Watershed: in quadrant 1 are LMDH and KTH as Subject that have high interest and low influence, quadrant 2 are Jember Regional Forestry Service, Public Company Perhutani Forest Management Unit Jember, and BPDASHL Brantas Sampean as Key Player that have high interest and high influence, quadrant 3 are Jember Recency Enviromental Service, Regional Planning and Development Agency Jember, Department of Public Works Highways and Water Resources Jember Regency, and Department of Food Crops, Horticulture, and Plantation Jember Regency as Context Setters that have low interest and high influence, and quadrant 4 is Brantas Sampean Watershed Forum as Crowd that have low interest and low influence.

\section{ACKNOWLEDGMENTS}

Acknowledgments for Postgraduate Research Grants-Student Thesis Research from Ministry of Research, Technology and Higher Education in 2019, led by Dr. Idah Andriyani and member lecturer Dr. Luh Putu Suciati. Thank you to the stakeholders I chose as key informants.

\section{REFERENCES}

Arsyad S. 1989. Konservasi Tanah dan Air. Bogor (ID): Institut Pertanian Bogor Press.

Arsyad S, Ernan R. 2008. Penyelamatan Tanah, Air, dan Lingkungan. Bogor (ID): Crestpent Press.

Andriyani I, Wahyuningsih S, Arumsari R. 2020. Penentuan Tingkat Bahaya Erosi di Wilayah DAS Bedadung Kabupaten Jember. Jurnal Ilmiah Rekayasa dan Biosistem. 8(1): 1-12.

Fadila Y. 2019. Pengaruh jenis tanah terhadap erosi pada Sub DAS Kemuning, Bintoro, dan Antrokan Kabupaten Jember [skripsi]. Jember (ID): Universitas Jember.

Fandeli C. 2012. Bisnis Konservasi Pendekatan Baru dalam Pengelolaan Sumberdaya Alam dan Lingkungan. Yogyakarta (ID): Universitas Gadjah Mada Press.

Handayani N. 2014. Mekanisme hubungan para pihak dalam pengelolaan wisata alam di zona pemanfaatan plengkung Taman Nasional Alas Purwo [skripsi]. Bogor (ID): Institut Pertanian Bogor.

Kartasapoetra AG. 2010. Teknologi Konservasi Tanah dan Air. Jakarta (ID): Rineka Cipta.

Kartika I, Indarto, Pudjono M, Ahmad H. 2016. Pemetaan tingkat bahaya erosi pada level sub DAS: Studi pada dua DAS identik. Jurnal Aroteknologi. 10(1): 117-128.

Kartikasari A. 2018. Identifikasi perubahan tata guna lahan DAS Bedadung Kabupaten Jember menggunakan Citra Satelit Landsat-8 [skripsi]. Jember (ID): Universitas Jember. 
Mawardi I. 2010. Kerusakan daerah aliran sungai dan penurunan daya dukung sumberdaya air di Pulau Jawa serta upaya penanganannya. Jurnal Hidrosfir Indonesia. 5(2): 1-11.

Ministry of Forestry. 2013. Petunjuk Teknis Penyusunan Data Spasial Lahan Kritis. Jakarta (ID): Ministry of Forestry in Republik of Indonesia.

Nazir M. 1999. Metode Penelitian. Jakarta (ID): Ghalia Indonesia.

Noviati. 2014. Optimalisasi peran Lembaga Masyarakat Desa Hutan (LMDH) bangun dalam meningkatkan partisipasi petani di Desa Donorejo. Geo Image. 3(1): 1-7.

Pramono DS. 2021. Misteri Luas Kecukupan Kawasan Hutan [Internet]. [Accessed 2021 Jul 3]. Available at: www.agroindonesia.co.id.

Rohman KM. 2018. Pengaruh perubahan tata guna lahan terhadap erosi menggunakan Metode Universal Soil Loss Equation (USLE) di DAS Bedadung [skripsi]. Jember (ID): Universitas Jember.

Rosyidie A. 2013. Banjir: Fakta dan dampaknya, serta pengaruhnya dari perubahan guna lahan. Journal of Regional and City Plannimg. 24(3): 241-249.

Santoso B, Handrijanto K, Rahmawi A, Jannah R. 2013. Model Intervensi Pengelolaan Daerah Aliran Sungai (DAS) (Community Based Action Research Pada Masyrakat di Daerah Aliran Sungai Bedadung Kabupaten Jember). Jember (ID): Universitas Jember.

Siregar M. 2011. Peranan stakeholder terhadap pengembangan ekowisata di Taman Nasional Teluk Cendrawasih Kabupaten Teluk Wondama Provinsi Papua Barat [thesis]. Bogor (ID): IPB.

Sukartaatmadja. 2004. Konversi Tanah dan Air. Bogor (ID): Institut Pertanian Bogor.

Suporahardjo. 2005. Manajemen Kolaborasi: Memahami Pluralisme Membangun Konsensus. Bogor (ID): Pustaka Latin.

Suryaningtias S. 2019. Penentuan tingkat bahaya erosi di Sub DAS Rembangan, Sub DAS Rempangan, dan DAS Sub DAS Jompo Kabupaten Jember [skripsi]. Jember (ID): Universitas Jember.

Wardhono, Adhitya, Rondhi M. 2010. Perhitungan kerusakan dan kerugian dalam perspektif ekonomi dan sosial dengan metode ECLAC bencana banjir bandang Panti Kabupaten Jember. Seminar Nasional Bahaya Banjir dan Sedimen; 2010 Oct 21; Magelang. Indonesia. Magelang (ID): Direktorat Jendral Sumberdaya Air Kementerian PU bekerjasama dengan Magister Pengelolaan Bencana Alam Fakultas Teknik UGM. p 1-20.

Widiyanti H. 2016. Strategi tata kelola pengembangan ekowisata di Taman Wisata Alam Kawah Ijen Provinsi Jawa Timur [thesis]. Bogor (ID): IPB.

Widodo, Listyo M, Soekandi R, Arifin H. 2018. Analisis stakeholders dalam pengembangan ekowisata di Taman Nasional Betung Kerihun Kabupaten Kapuas Hulu. Jurnal Pengelolaan Sumberdaya Alam dan Lingkungan. 8(1): 55-61. 